\title{
Everolimus-eluting stents: update on current clinical studies
}

This article was published in the following Dove Press journal:

Medical Devices: Evidence and Research

25 July $201 \mathrm{I}$

Number of times this article has been viewed

\section{Dominic J Allocco \\ Anita A Joshi \\ Keith D Dawkins}

Boston Scientific Corporation, Natick, MA, USA

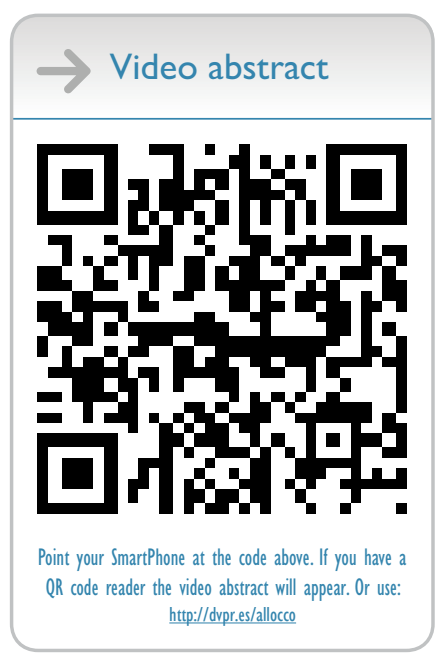

Correspondence: Dominic J Allocco Boston Scientific Corporation,

One Scimed Place, Maple Grove,

MN 553I, USA

$\mathrm{Tel}+\mathrm{I} 7634941985$

Fax +I 7634942111

Email dominic.allocco@bsci.com
Abstract: Everolimus-eluting stents (EES) have become the most commonly implanted coronary stents worldwide. This review describes and analyzes the clinical data supporting the use of EES, focusing primarily on published, randomized, controlled trials. Everolimuseluting stents have been shown to have less restenosis, stent thrombosis, and periprocedural myocardial infarction compared with earlier generation paclitaxel-eluting stents (PES). Lower rates of adverse events for EES compared with PES were generally seen in all subgroups, with the notable exception of patients with diabetes mellitus. There have been fewer, randomized, clinical trials comparing EES with either sirolimus-eluting stents or zotarolimus-eluting stents, although very good results with EES have been observed in the trials that have been performed Recent clinical trial data suggest that this excellent safety and efficacy profile is maintained in a next-generation EES designed to have improved mechanical properties and radiopacity.

Keywords: drug-eluting stents, everolimus, Xience V, Promus, Promus Element

\section{Introduction}

Since their introduction in 2002, drug-eluting stents (DES) have become a mainstay of percutaneous coronary intervention. By releasing antiproliferative, anti-inflammatory drugs directly into the arterial wall, DES inhibit the development of neointimal hyperplasia, the principal cause of restenosis after stenting. First-generation DES, such as the sirolimus-eluting Cypher ${ }^{\circledR}$ stent (Cordis, Johnson and Johnson, Bridgewater, NJ) and the paclitaxel-eluting Taxus Express ${ }^{\circledR}$ stent (Boston Scientific Corporation, Natick, MA) demonstrated reduced clinical and angiographic restenosis compared with bare-metal stents (BMS).$^{1,2}$ However, potentially higher rates of late and very late stent thrombosis, likely due to delayed and incomplete endothelialization, emerged as a significant concern. ${ }^{3-8}$ In an attempt to enhance the safety and efficacy of DES further, zotarolimus-eluting stents (ZES) and everolimus-eluting stents (EES) were introduced. EES in particular have become widely adopted and are now the most commonly used stents worldwide. This review describes EES that are commercially available and summarizes the clinical data supporting their use, focusing primarily on published, randomized, controlled trials.

\section{Pharmacology/design}

Everolimus, an analog of rapamycin (sirolimus), is an immunosuppressive and antiproliferative agent. ${ }^{9,10}$ The chemical structure of everolimus is presented in Figure 1. The cellular actions of everolimus are mediated by binding to its intracellular receptor, FKBP12. This complex interferes with FKBP12 rapamycin-associated protein, also known as mTOR (mammalian target of rapamycin), leading to inhibition of cell 


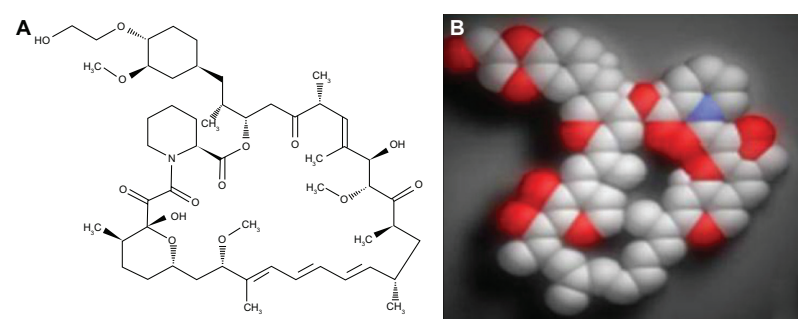

Figure I Everolimus: (A) molecular structure and (B) 3-dimensional structure. Due to its chemical structure, everolimus is more lipophilic than sirolimus, allowing rapid absorption in the arterial wall following everolimus-eluting stent implantation.

metabolism, growth, and proliferation, by arresting growth at the late G1 stage. Everolimus acts on several cell types, including vascular smooth muscle cells, and has been shown to inhibit neointimal growth following coronary stent implantation in experimental models. ${ }^{11}$ Due to its chemical structure, everolimus is more lipophilic than sirolimus. As a result, it is more rapidly absorbed into the arterial wall, potentially making it a better drug for local intravascular delivery following stent implantation. ${ }^{12}$

The first EES to be commercially available were Xience $\mathrm{V}^{\circledR}$ (Abbott Vascular, Santa Clara, CA) and Promus ${ }^{\circledR}$ (Boston Scientific Corporation, Natick, MA). The identical stent is manufactured by Abbott Vascular (Santa Clara, CA) and distributed as Xience V by Abbott Vascular and as Promus by Boston Scientific Corporation. Xience V/Promus consists of a balloon expandable Multi-Link Vision stent manufactured from an L-605 cobalt-chromium alloy with a strut thickness of $81 \mu \mathrm{m}$. The stent is coated with a polymer consisting of two layers, a poly n-butyl methacrylate primer layer and a nonadhesive, durable, biocompatible drug matrix layer. The drug matrix layer is composed of a copolymer of polyvinylidene fluoride and hexafluoropropylene blended with everolimus.

Xience $^{\circledR}$ Prime $^{\mathrm{TM}}$ (Abbott Vascular) is a more current version of the Xience V/Promus, utilizing the same drug and polymer formulation as Xience V/Promus in combination with a modified stent design and delivery system designed for greater flexibility and enhanced deliverability. More recently, Boston Scientific Corporation has developed a novel platinum-chromium stent platform (Figure 2) designed to improve deliverability and conformability, whilst increasing radiopacity, radial strength, and fracture resistance, and reducing recoil. ${ }^{13}$ Promus $^{\circledR}$ Element ${ }^{\mathrm{TM}}$ combines the same drug and polymer formulation as Xience V/Promus with this new platinum-chromium stent platform.

\section{Clinical studies}

The clinical feasibility of using everolimus on a DES was first demonstrated in the FUTURE I and FUTURE II trials. ${ }^{14-16}$ Both trials utilized the Challenge ${ }^{\mathrm{TM}}$ EES (Biosensors International, Kampong Ubi, Singapore). This system comprised a stainless steel S-stent ${ }^{\mathrm{TM}}$ coated with a bioabsorbable polymer (polylactic acid) matrix releasing everolimus. In the FUTURE I trial, 42 patients were randomized in a 2:1 ratio to either EES or BMS. In the FUTURE II trial, 64 patients were randomized in a 1:2 ratio to either EES or BMS. At 6-month follow-up, EES had a lower in-stent late lumen loss (FUTURE I: 0.11 vs $0.85 \mathrm{~mm}, P<0.001$; FUTURE II: 0.12 vs $0.85 \mathrm{~mm}$, $P<0.001)$. Although the Challenge EES was never commercialized, results of the FUTURE trials demonstrated that this EES was more efficacious in reducing neointimal proliferation compared with BMS.

\section{SPIRIT Clinical Trial Program}

The subsequent SPIRIT Clinical Trial Program was undertaken to evaluate the safety and efficacy of the Xience V/Promus EES system. A summary of the SPIRIT trials is presented in Table 1. Based on the results of initial studies, including SPIRIT FIRST, II, and III, the Xience V/Promus stent gained approval for commercial use in Europe in 2006 and in the US in 2008.

The SPIRIT FIRST trial was a prospective, single-blind, randomized, multicenter trial that compared outcomes in patients treated with Xience V/Promus vs BMS. Sixty patients with a single de novo coronary artery lesion were randomized 1:1 to either a Xience V EES or a Multi-Link Vision BMS (the same stent platform as used in Xience V/Promus). The primary endpoint was in-stent late loss at 6 months. At 6 months, the in-stent late loss, percent diameter stenosis, and percentage of patients with binary restenosis were $0.10 \mathrm{~mm}$, $16 \%$, and $0 \%$ respectively, in the EES group, compared with $0.87 \mathrm{~mm}, 39 \%$, and $25.9 \%$, respectively, in the BMS group $(P<0.001$ for late loss and diameter stenosis, $P=0.01$ for restenosis). Significantly less percent volume obstruction was observed in the EES group compared with the BMS group $(8.0 \% \pm 10.4 \%$ vs $28.1 \% \pm 14.0 \%, P<0.001) .{ }^{17}$ At 1 -year follow-up, the in-stent late loss was still significantly lower in the EES group $(0.24 \mathrm{~mm}$ vs $0.84 \mathrm{~mm}, P<0.001)$, but was increased from 6 months. Significantly less percent volume obstruction was still observed in the EES group compared with the BMS group $(10 \% \pm 7 \%$ vs $28 \% \pm 12 \%$, $P<0.001)$. The overall major adverse cardiac events (MACE) rate at 1 year was numerically lower in the EES group (15.4\% vs $21.4 \%) .{ }^{18}$ Weimer et al recently reported the 5-year clinical follow-up data on SPIRIT FIRST. ${ }^{19}$ Although a small patient population, this report represents the longest clinical follow-up data on Xience V/Promus to date. At 5-year clinical follow-up, no new events were observed for 1-5 


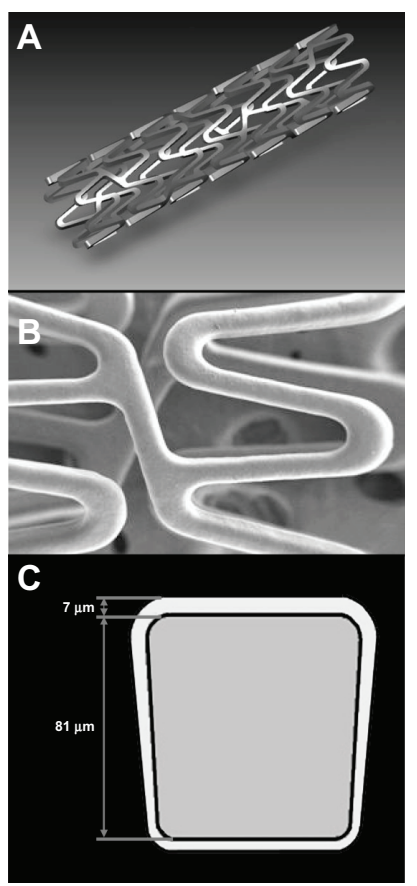

Figure 2 Promus Element platinum chromium everolimus-eluting stent. (A) Normal view, (B) magnified view, and (C) cross-sectional view. Promus Element uses the same drug and polymer as Xience V/Promus, but has been modified to provide improved deliverability, conformability, radiopacity, radial strength, and fracture resistance.

years in the EES group. No stent thromboses were observed in either the EES or BMS groups up to 5 years.

SPIRIT II was a prospective, single-blind, multicenter, noninferiority clinical trial in which 300 patients with a maximum of two de novo coronary artery lesions located in two different epicardial vessels were randomized 3:1 to either a Xience V EES or Taxus Express² paclitaxel-eluting stent (PES). The primary endpoint of 6-month in-stent late loss was significantly lower in the EES group compared with the PES group $(0.11 \pm 0.27 \mathrm{~mm}$ vs $0.36 \pm 0.39 \mathrm{~mm}$, $P<0.0001)$. Percent volume obstruction in the EES group was also significantly lower compared with the PES group $(2.5 \% \pm 4.7 \%$ vs $7.4 \% \pm 7.0 \%, P<0.0001) .{ }^{20}$ Although this study was not powered to assess clinical endpoints, at 1-year clinical follow-up, the rate of MACE was significantly lower in the EES group compared with the PES group (2.7\% vs $9.2 \%, P=0.04) .{ }^{21}$ At 2 -year follow-up, there were no significant differences between EES and PES for in-stent late loss $(0.33 \pm 0.37 \mathrm{~mm}$ vs $0.34 \pm 0.34 \mathrm{~mm}, P=0.84)$ and percent volume obstruction $(5.18 \% \pm 6.22 \%$ vs $5.80 \% \pm 6.31 \%$, $P=0.65) .{ }^{22}$ At 3 and 4 years, there was a continued trend for lower MACE rates $(7.2 \%$ vs $15.9 \%, P=0.053$ and $7.7 \%$ vs $16.4 \%, P=0.056$, respectively). ${ }^{23,24}$

SPIRIT III was a prospective, single-blind, randomized, pivotal clinical trial in which 1002 patients with either one or two de novo coronary artery lesions were randomized 2:1 to either a Xience V EES or a Taxus Express ${ }^{2}$ PES. The primary endpoint was in-segment late lumen loss at 8 months. Angiographic in-segment late loss was significantly lower in the EES group compared with the PES group $(0.14 \pm 0.41 \mathrm{~mm}$ vs $0.28 \pm 0.48 \mathrm{~mm}, P \leq 0.004)$. The EES was noninferior to the PES $(7.2 \%$ vs $9.0 \%, P<0.001)$ for the 9 -month endpoint of target vessel failure, defined as cardiac death, myocardial infarction, or target vessel revascularization. Also, the use of EES compared with PES resulted in significant reductions in MACE (cardiac death, myocardial infarction, or target lesion revascularization) at 1 year $(6.0 \%$ vs $10.3 \%, P=0.02)$. No significant differences were observed between the two devices in the rates of early or late stent thrombosis. ${ }^{25}$ Through 4 years, the rates of the composite safety and efficacy measures of target lesion failure and MACE were significantly lower in the EES group compared with the PES group, with no significant difference in the rate of target vessel failure. No significant differences were observed in the rates of death, myocardial infarction, and stent thrombosis. ${ }^{26}$

Although EES demonstrated superior angiographic outcomes in the SPIRIT II and III trials, neither of these studies was powered to show the clinical superiority of EES. The SPIRIT IV trial was designed to assess potential differences in clinical outcomes in a slightly more complex patient population than was studied in the prior SPIRIT studies. It also did not include mandatory angiographic follow-up to avoid artificially increasing the target lesion revascularization rates. ${ }^{27}$

SPIRIT IV was a single-blind, randomized, multicenter post-approval study in which 3687 patients with up to three de novo coronary artery lesions were randomized 2:1 to either a Xience V EES or a Taxus Express ${ }^{2}$ PES. Approximately $32 \%$ of patients had diabetes mellitus. The EES was superior to the PES with respect to the primary endpoint of target lesion failure $(4.2 \%$ vs $6.8 \%, P=0.001)$ at 1 year. The rates of ischemia-driven target lesion revascularization $(2.5 \% \mathrm{vs}$ $4.6 \%, P=0.001)$, myocardial infarction $(1.9 \%$ vs $3.1 \%$, $P=0.02)$, and stent thrombosis $(0.17 \%$ vs $0.85 \%, P=0.004)$ were significantly lower with EES compared with PES. Target lesion failure was consistently reduced with EES compared with PES in 12 prespecified subgroups, except in patients with diabetes mellitus $(6.4 \%$ vs $6.9 \%, P=0.80) .{ }^{28}$ Through 2 years, the rates of target lesion failure, ischemia-driven target lesion revascularization, myocardial infarction, and stent thrombosis remained significantly lower in the EES group. Similar to 1-year results, target lesion failure was lower with EES in all subgroups assessed except for patients with diabetes mellitus $(9.8 \%$ vs $10.6 \%, P=0.68) .{ }^{29}$ 
Table I SPIRIT clinical trial program

\begin{tabular}{|c|c|c|c|c|c|c|c|}
\hline$\overline{\text { Study }}$ & Design & Lesion type & $\begin{array}{l}\text { Lesion } \\
\text { length }\end{array}$ & $\begin{array}{l}\text { Baseline } \\
\text { RVD }\end{array}$ & Control & Primary endpoint & Enrollment \\
\hline SPIRIT FIRST & $\begin{array}{l}\text { Prospective, } \\
\text { multicenter, } \\
\text { randomized, } \\
\text { single-blind }\end{array}$ & De novo & $\leq 12 \mathrm{~mm}$ & $3.0 \mathrm{~mm}$ & BMS & $\begin{array}{l}\text { In-stent late loss } \\
\text { at } 180 \text { days }\end{array}$ & 60 \\
\hline SPIRIT II & $\begin{array}{l}\text { Prospective, } \\
\text { multicenter, } \\
\text { randomized, } \\
\text { single-blind }\end{array}$ & $\begin{array}{l}\text { Up to } 2 \text { de novo } \\
\text { in different vessels }\end{array}$ & $\leq 28 \mathrm{~mm}$ & $2.5-4.25 \mathrm{~mm}$ & $\begin{array}{l}\text { TAXUS } \\
\text { Express }^{2}\end{array}$ & $\begin{array}{l}\text { In-stent late loss } \\
\text { at } 180 \text { days }\end{array}$ & 300 \\
\hline SPIRIT III & $\begin{array}{l}\text { Prospective, } \\
\text { multicenter, } \\
\text { randomized, } \\
\text { single-blind }\end{array}$ & $\begin{array}{l}\text { Up to } 2 \text { de novo } \\
\text { in different vessels } \\
\text { (maximum I per } \\
\text { vessel) }\end{array}$ & $\leq 28 \mathrm{~mm}$ & $2.5-3.75 \mathrm{~mm}$ & $\begin{array}{l}\text { TAXUS } \\
\text { Express }^{2}\end{array}$ & $\begin{array}{l}\text { In-segment late loss } \\
\text { at } 240 \text { days }\end{array}$ & 1002 \\
\hline SPIRIT IV & $\begin{array}{l}\text { Prospective, } \\
\text { multicenter, } \\
\text { randomized, } \\
\text { single-blind }\end{array}$ & $\begin{array}{l}\text { Up to } 3 \text { de novo } \\
\text { native coronary } \\
\text { lesions (maximum } \\
2 \text { per vessel) }\end{array}$ & $\leq 28 \mathrm{~mm}$ & $2.5-3.75 \mathrm{~mm}$ & $\begin{array}{l}\text { TAXUS } \\
\text { Express }^{2}\end{array}$ & $\begin{array}{l}\text { I2-month ischemia-driven } \\
\text { TLF (cardiac death, } \\
\text { target-vessel MI, TLR) }\end{array}$ & 3687 \\
\hline $\begin{array}{l}\text { SPIRIT V } \\
\text { diabetic study }\end{array}$ & $\begin{array}{l}\text { Prospective, } \\
\text { randomized, } \\
\text { single-blind, } \\
\text { multicenter }\end{array}$ & $\begin{array}{l}\text { One de novo target } \\
\text { lesion per vessel } \\
\text { (maximum } 4 \text { planned } \\
\text { stents) }\end{array}$ & $\leq 28 \mathrm{~mm}$ & $2.25-4.0 \mathrm{~mm}$ & $\begin{array}{l}\text { TAXUS } \\
\text { Liberté }\end{array}$ & $\begin{array}{l}\text { In-stent late loss } \\
\text { at } 270 \text { days }\end{array}$ & 324 \\
\hline $\begin{array}{l}\text { SPIRIT V } \\
\text { registry }\end{array}$ & $\begin{array}{l}\text { Prospective, } \\
\text { single-arm, } \\
\text { multicenter }\end{array}$ & $\begin{array}{l}\text { De novo target } \\
\text { lesions }\end{array}$ & $\leq 28 \mathrm{~mm}$ & $2.5-4.0 \mathrm{~mm}$ & None & $\begin{array}{l}\text { 30-day composite } \\
\text { of all death, } \\
\text { MI, and TVR }\end{array}$ & 2663 \\
\hline XIENCE V USA & $\begin{array}{l}\text { Prospective, } \\
\text { multicenter, } \\
\text { single-arm } \\
\text { registry }\end{array}$ & All inclusive & Not defined & Not defined & None & $\begin{array}{l}\text { Adjudicated 30-day } \\
\text { composite of all } \\
\text { death, MI, TVR }\end{array}$ & 5054 \\
\hline $\begin{array}{l}\text { XIENCE V: } \\
\text { SPIRIT WOMEN }\end{array}$ & $\begin{array}{l}\text { Prospective, } \\
\text { single-arm, } \\
\text { multicenter }\end{array}$ & $\begin{array}{l}\text { De novo coronary } \\
\text { artery lesions } \\
\text { (maximum } 4 \\
\text { planned stents) }\end{array}$ & $\leq 28 \mathrm{~mm}$ & $2.5-4.0 \mathrm{~mm}$ & None & $\begin{array}{l}\text { Adjudicated composite } \\
\text { death, MI, and } \\
\text { TVR at I year }\end{array}$ & 1600 \\
\hline XIENCE V India & $\begin{array}{l}\text { Prospective, } \\
\text { multicenter } \\
\text { single arm } \\
\text { registry }\end{array}$ & All inclusive & Not defined & Not defined & None & $\begin{array}{l}\text { ST (ARC definitions) } \\
\text { annually to } 5 \text { years; } \\
\text { composite of cardiac } \\
\text { death and any } \mathrm{Ml} \text { at I year }\end{array}$ & 1000 \\
\hline $\begin{array}{l}\text { XIENCE V } \\
\text { EXCEED }\end{array}$ & $\begin{array}{l}\text { Prospective, } \\
\text { single-arm, } \\
\text { observational } \\
\text { study }\end{array}$ & All inclusive & Not defined & Not defined & None & $\begin{array}{l}\text { Physician-determined } \\
\text { acute performance } \\
\text { and deliverability }\end{array}$ & 2517 \\
\hline $\begin{array}{l}\text { SPIRIT Small } \\
\text { vessel }\end{array}$ & Open-label & $\begin{array}{l}\text { Up to } 2 \text { de novo } \\
\text { native coronary } \\
\text { lesions }\end{array}$ & $\leq 28 \mathrm{~mm}$ & $2.25-2.5 \mathrm{~mm}$ & None & $\begin{array}{l}\text { Composite of cardiac } \\
\text { death, target vessel } \\
\text { MI, and clinically } \\
\text { driven TLR at I year }\end{array}$ & 150 \\
\hline
\end{tabular}

Abbreviations: ARC, academic research consortium; BMS, bare metal stents; MI, myocardial infarction; mm, millimeter; RVD, reference vessel diameter; ST, stent thrombosis; TLF, target lesion failure; TLR, target lesion revascularization; TVR, target vessel revascularization.

The SPIRIT V Diabetic Study was a randomized, single-blind, multicenter study comparing Xience V EES with the second-generation Taxus Liberté PES in the treatment of patients with diabetes mellitus. Three hundred and twenty-four patients were randomized 2:1 to either Xience V EES or Taxus Liberté PES (Boston Scientific Corporation, Natick, MA). For the 9-month primary endpoint of in-stent late loss, EES was superior to PES $(0.19 \pm 0.37 \mathrm{~mm}$ vs $0.39 \pm 0.49 \mathrm{~mm}, P=0.0001)$. At 1 -year, although the differences were not statistically significant in this relatively small study, there was a trend towards lower rates of cardiac death $(0.5 \%$ vs $2.9 \%, P=0.10)$, myocardial infarction $(3.3 \%$ vs $8.7 \%, P=0.05)$, and stent thrombosis $(0.0 \%$ vs $1.9 \%, P=0.11)$ in the EES group compared with the PES group. However, in the case of target lesion revascularization, there was a trend towards a lower rate 
in the PES group compared with the EES group (11.2\% vs $6.7 \%, P=0.23) .{ }^{30}$

Besides the aforementioned randomized trials which demonstrated the safety and efficacy of EES in selected patients, other studies in the SPIRIT program, described in Table 1, have been designed to evaluate the safety and performance of EES in "real-world" settings. These studies include the SPIRIT V study, XIENCE V USA, and XIENCE V India. In the SPIRIT V study, the 1-year rates of MACE, stent thrombosis, and target lesion revascularization in complex patients were similar to those observed in the simple patient populations included in the SPIRIT II and III trials. ${ }^{31}$ Through 2 years, the rate of definite or probable stent thrombosis was low $(0.79 \%){ }^{32}$ Similarly, in the XIENCE V USA study, which was designed to evaluate the continued safety of Xience V, a low rate of stent thrombosis $(0.84 \%)$ was observed in a "real-world" patient population at 1 year. ${ }^{33}$

\section{Other clinical studies of everolimus-eluting stents}

COMPARE was a randomized, open-label study that also evaluated the safety and efficacy of EES vs PES in "realworld" practice. One thousand eight hundred consecutive patients at a single center were randomized 1:1 to either Xience V EES or Taxus Liberté PES. At the 12-month primary endpoint, a composite of all-cause mortality, nonfatal myocardial infarction, and target vessel revascularization, EES was superior to PES $(6.0 \%$ vs $9.0 \%, P=0.02)$. The difference was attributable to lower rates of stent thrombosis $(0.7 \%$ vs $3.0 \%, P=0.002)$, myocardial infarction $(3.0 \%$ vs $5.0 \%, P=0.007)$, and target vessel revascularization $(2.0 \%$ vs $6.0 \%, P=0.0001)$ in the EES group compared with the PES group. Rates of all-cause mortality or cardiac death did not differ between the two groups. ${ }^{34}$ Similar to the 1 -year results, at 2-year follow-up, the composite endpoint of allcause mortality, nonfatal myocardial infarction, and target vessel revascularization, and the secondary endpoint of MACE (cardiac death, nonfatal myocardial infarction, and target lesion revascularization) were significantly lower in the EES group compared with the PES group. The rate of definite or probable stent thrombosis remained significantly lower in the EES group compared with the PES group $(0.9 \%$ vs $3.9 \%, P<0.001)$. Subgroup analysis demonstrated better outcomes with EES compared with PES, except in patients with diabetes mellitus (relative risk 0.94; 95\% confidence interval [CI]: 0.55-1.62). ${ }^{35}$

The EXECUTIVE study was designed to assess the performance of Xience V/Promus EES in the treatment of patients with multivessel disease. It was a prospective, double-arm, randomized, multicenter trial to assess the angiographic efficacy of EES compared with PES and a prospective, open-label, single-arm registry to analyze the clinical efficacy and safety of EES in patients treated for multivessel disease. ${ }^{36}$ In the randomized trial, 200 patients were randomized 1:1 to receive either Xience V/Promus EES or Taxus Liberté PES. The primary endpoint of in-stent late loss at 9 months was significantly lower in the EES group compared with the PES group $(0.08 \mathrm{~mm}$ vs $0.22 \mathrm{~mm}$, $P=0.018$ ), corroborating previous observations in patients with less complex disease. ${ }^{37}$ The EXCEL trial evaluating Xience V/Xience Prime EES vs coronary artery bypass graft surgery in patients with unprotected left main coronary artery disease will provide additional information on the safety and efficacy of EES for the treatment of patients with complex lesion characteristics.

\section{Everolimus-eluting stents vs sirolimus-eluting stents}

SORT OUT-IV was designed as a randomized, multicenter, open-label, all-comer, noninferiority study to compare Xience V/Promus EES vs Cypher Select ${ }^{\circledR}$ Plus SES (Cordis, Johnson and Johnson, Bridgewater, NJ) in the treatment of unselected patients. The primary endpoint was a composite of cardiac death, myocardial infarction, definite stent thrombosis, and target vessel revascularization at 9 months. ${ }^{38}$ Two thousand seven hundred and seventy-four patients were randomized between EES and SES. At the 9-month primary endpoint, EES was noninferior to SES (4.9\% vs $5.2 \%, P=0.01)$. The rates of cardiac death $(1.9 \%$ vs $1.4 \%$, $P=0.31)$, myocardial infarction $(1.1 \%$ vs $1.4 \%, P=0.48)$, target vessel revascularization $(2.8 \%$ vs $3.5 \%, P=0.32)$, and target lesion revascularization $(1.4 \%$ vs $1.7 \%, P=0.64)$ were low and comparable between the two groups. There was a trend towards a lower rate of definite stent thrombosis in the EES group compared with the SES group (0.1\% vs $0.7 \%$, $P=0.05) .{ }^{39}$

The EXCELLENT trial, a prospective, randomized, multicenter, open-label, trial was designed to compare the safety and efficacy of Xience V/Promus EES vs Cypher Select SES. The primary endpoint was in-segment late loss at 9 months. ${ }^{40}$ One thousand four hundred and forty-three patients were randomized 3:1 between EES and SES. At the 9-month primary endpoint, EES was noninferior to SES $(0.10 \pm 0.36$ vs $0.05 \pm 0.34, P$ for noninferiority was 0.02$)$. The rates of clinical events including composite of cardiac death or myocardial infarction $(1.5 \%$ vs $1.9 \%, P=0.56)$, 
target lesion revascularization $(2.4 \%$ vs $1.7 \%, P=0.40)$, target lesion failure $(3.7 \%$ vs $3.0 \%, P=0.55)$ and definite or probable stent thrombosis were not significantly different between the two groups $(0.4 \%$ vs $0.8 \%, P=0.28){ }^{41}$

In a subanalysis of 1304 patients randomized between Xience V/Promus EES and Cypher SES in the ISAR-TEST 4 study, there was no significant difference in the combined endpoint of cardiac death, target vessel myocardial infarction, and target lesion revascularization between the EES and SES groups $(16.0 \%$ vs $18.8 \%, P=0.23)$ at 2 years. Similarly, definite or probable stent thrombosis $(1.4 \%$ vs $1.9 \%, P=0.52)$ and target lesion revascularization $(9.9 \%$ vs $13.5 \%, P=0.06)$ were not significantly different between the two groups. ${ }^{42}$

The X-SEARCH registry evaluated the performance of EES in comparison with SES in more complex, unselected patients. At 6 months, the composite endpoint of MACE was not significantly different between EES and SES $(9.2 \%$ vs $7.3 \%, P=0.2)$. The rate of overall stent thrombosis was similar between the two groups $(0.6 \%$ vs $0.6 \%){ }^{43}$

The LESSON-1 study also compared the safety and efficacy of the unrestricted use of EES with SES in a large, consecutively enrolled patient population. At 3 years, the composite endpoint of death, myocardial infarction, or target vessel revascularization was not significantly different between the groups $(14.9 \%$ vs $18.0 \%, P=0.06)$. The rates of myocardial infarction $(3.3 \%$ vs $5.0 \%, P=0.02)$ and target vessel revascularization $(7.0 \%$ vs $9.6 \%, P=0.04)$ were significantly lower with EES compared with SES. The lower myocardial infarction rate observed in the EES group was partly attributed to lower rates of definite stent thrombosis $(0.5 \%$ vs $1.6 \%, P=0.01){ }^{44}$

\section{Everolimus-eluting stents vs zotarolimus-eluting stents}

The RESOLUTE All Comers trial was designed to compare Xience V/Promus EES with Endeavor ${ }^{\circledR}$ Resolute ZES (Medtronic, Santa Rosa, CA) in an unrestricted, multicenter, open-label, randomized, noninferiority trial. A total of 2292 patients were randomized to either EES or ZES. At the 1-year primary endpoint of target lesion failure, defined as a composite of cardiac death, myocardial infarction, or clinically indicated target lesion revascularization, ZES was noninferior to EES $(8.3 \%$ vs $8.2 \%, P<0.001$ for noninferiority). Resolute ZES was also noninferior regarding the degree of in-stent stenosis $(19.76 \% \pm 14.64 \%$ vs $21.65 \% \pm 14.42 \%, P=0.04$ for noninferiority). In-stent late lumen loss was not significantly different between the two groups $(0.19 \pm 0.40 \mathrm{~mm}$ vs $0.27 \pm 0.43 \mathrm{~mm}, P=0.08)$.
At 12 months, the rate of definite stent thrombosis was significantly higher in the ZES group $(0.3 \%$ vs $1.2 \%$, $P=0.01)$, primarily due to a higher rate of definite stent thrombosis in the ZES group at 30 days $(0.1 \%$ vs $0.8 \%$, $P=0.01)$. The rate of definite or probable stent thrombosis was $0.7 \%$ in the EES group compared with $1.6 \%$ in the ZES group $(P=0.05) .{ }^{45}$ Through 2 years, the rate of target lesion failure $(10.7 \%$ vs $11.2 \%, P=0.73)$ did not differ between groups. Three patients in each group $(0.3 \%)$ had very late (after 1 year) stent thrombosis. ${ }^{46}$

\section{Next-generation everolimus-eluting stent}

A total of 100 patients were enrolled in the PLATINUM quantitative coronary angiography substudy, a single arm trial designed to examine angiographic and intravascular ultrasound outcomes with Promus Element EES. The 30-day primary endpoint (cardiac death, myocardial infarction, target lesion revascularization, or definite and probable stent thrombosis occurred in $1.0 \%$ of patients, with no additional major clinical events through 1 year. The efficacy endpoints were in-stent late loss at 9 months and postprocedure incomplete stent apposition. The 9-month in-stent late loss was comparable for Promus Element $(0.17 \pm 0.25 \mathrm{~mm})$ with that previously reported for Xience V/Promus in the SPIRIT First, ${ }^{17}$ SPIRIT II, ${ }^{20}$ and SPIRIT III ${ }^{25}$ trials. Postprocedure incomplete stent apposition (5.7\%) was significantly less than that reported for XIENCE V/Promus EES in SPIRIT III (34.4\%, $P<0.001)$. This may reflect differences in stent design, but could also be related to other factors including the extensive use $(91.0 \%)$ of postdilatation and/or the maximum postdilatation balloon pressure $(18.0 \pm 3.6 \mathrm{~atm})$ in the PLATINUM quantitative coronary angiography study. ${ }^{47}$

The PLATINUM Workhorse trial, a prospective, multicenter, randomized, single-blind trial was designed to evaluate the safety and effectiveness of the Promus Element EES for the treatment of patients with up to two de novo coronary lesions. A total of 1530 patients were randomized 1:1 to either Promus EES or Promus Element EES. The primary endpoint was the 12-month rate of target lesion failure defined as target vessel-related cardiac death, target vesselrelated myocardial infarction, or ischemia-driven target lesion revascularization. At 12 months, Promus Element was noninferior to Promus EES for target lesion failure (Promus EES: $2.9 \%$, Promus Element: $3.4 \% ; P=0.001$ for noninferiority). There were no significant differences between Promus EES and Promus Element EES in the 12-month rates of cardiac death $(0.7 \%$ vs $0.9 \% P=0.58)$, myocardial infarction 
(1.8\% vs $1.1 \%, P=0.25)$, target lesion revascularization (1.9\% vs $1.9 \%, P=0.96)$, and definite or probable stent thrombosis $(0.4 \%$ vs $0.4 \%, P=1.00)$. Although the rates of technical and procedural success were similar with Promus EES and Promus Element EES, a higher rate of unplanned stenting $(9.8 \%$ vs $5.9 \%, P=0.004)$ attributable to inadequate lesion coverage ( $3.4 \%$ vs $1.4 \%, P=0.01)$ was observed with Promus EES compared with Promus Element EES. ${ }^{48}$

\section{Clinical implications and conclusion}

There are now extensive published clinical data supporting the safety and efficacy of EES. In comparison with earlier generation PES (Taxus Express and Taxus Liberté), EES have shown less restenosis, stent thrombosis, and periprocedural myocardial infarction. Lower rates of adverse events with EES compared with PES have generally been seen in all subgroups, with the notable exception of patients with diabetes mellitus. There have been fewer randomized clinical trials comparing EES with either SES or ZES, although very good results with EES have been observed in the trials that have been performed. Studies of the next-generation Promus Element EES have demonstrated successful transfer of the Xience V/Promus drug and polymer formulation to a stent platform designed for improved deliverability and radiopacity.

The strong base of evidence supporting the safety and efficacy of EES is undoubtedly one of the key factors contributing to the widespread use of EES worldwide. However, a number of important questions regarding EES remain unanswered, including among others, the optimal duration of dual antiplatelet therapy, the optimal antiplatelet regimen for anticoagulated patients, the long-term outcomes with EES, particularly in complex patients and lesions, the relative performance of EES compared with newer DES (overall and in specific subgroups), and the utility of bioabsorbable polymers/stents or polymer-free systems for everolimus delivery. The results of ongoing trials will provide additional information on these key clinical questions.

\section{Disclosure}

All authors are full-time employees of Boston Scientific Corporation and Drs Allocco and Dawkins are stockholders of Boston Scientific Corporation.

\section{References}

1. Moses JW, Leon MB, Popma JJ, et al. Sirolimus-eluting stents versus standard stents in patients with stenosis in a native coronary artery. $N$ Engl J Med. 2003;349:1315-1323.
2. Stone GW, Ellis SG, Cox DA, et al. A polymer-based paclitaxel-eluting stent in patients with coronary artery disease. $N$ Engl J Med. 2004; 350:221-231.

3. Kotani J, Awata M, Nanto S, et al. Incomplete neointimal coverage of sirolimus-eluting stents: angioscopic findings. J Am Coll Cardiol. 2006; 47:2108-2111.

4. Finn AV, Joner M, Nakazawa G, et al. Pathological correlates of late drug-eluting stent thrombosis: strut coverage as a marker of endothelialization. Circulation. 2007;115:2435-2441.

5. Ong AT, McFadden EP, Regar E, de Jaegere PP, van Domburg RT, Serruys PW. Late angiographic stent thrombosis (LAST) events with drug-eluting stents. J Am Coll Cardiol. 2005;45:2088-2092.

6. Pfisterer M, Brunner-La Rocca HP, Buser PT, et al. Late clinical events after clopidogrel discontinuation may limit the benefit of drug-eluting stents: an observational study of drug-eluting versus bare-metal stents. J Am Coll Cardiol. 2006;48:2584-2591.

7. Daemen J, Wenaweser P, Tsuchida K, et al. Early and late stent thrombosis of sirolimus-eluting and paclitaxel-eluting stents in routine clinical practice: data from a large two-institutional cohort study. Lancet. 2007;369:667-678.

8. Stone GW, Moses JW, Ellis SG, et al. Safety and efficacy of sirolimusand paclitaxel-eluting coronary stents. N Engl J Med. 2007;356: 998-1008.

9. Schuler W, Sedrani R, Cottens S, et al. SDZ RAD, a new rapamycin derivative: pharmacological properties in vitro and in vivo. Transplantation. 1997;64:36-42.

10. Marx SO, Marks AR. Bench to bedside: The development of rapamycin and its application to stent restenosis. Circulation. 2001;104: $852-855$.

11. Waksman R, Pakala R, Baffour R, et al. Optimal dosing and duration of oral everolimus to inhibit in-stent neointimal growth in rabbit iliac arteries. Cardiovasc Revasc Med. 2006;7:179-184.

12. Kahan BD, Wong RL, Carter C, et al. A phase I study of a 4-week course of SDZ-RAD (RAD) quiescent cyclosporine-prednisone-treated renal transplant recipients. Transplantation. 1999;68:1100-1106.

13. Menown IB, Noad R, Garcia EJ, Meredith I. The platinum chromium element stent platform: from alloy, to design, to clinical practice. Adv Ther. 2010;27:129-141.

14. Costa RA, Lansky AJ, Mintz GS, et al. Angiographic results of the first human experience with everolimus-eluting stents for the treatment of coronary lesions (the FUTURE I trial). Am J Cardiol. 2005; 95:113-116.

15. Grube E, Sonoda S, Ikeno F, et al. Six- and twelve-month results from first human experience using everolimus-eluting stents with bioabsorbable polymer. Circulation. 2004;109:2168-2171.

16. Tsuchiya Y, Lansky AJ, Costa RA, et al. Effect of everolimus-eluting stents in different vessel sizes (from the pooled FUTURE I and II trials). Am J Cardiol. 2006;98:464-469.

17. Serruys PW, Ong AT, Piek JJ, et al. A randomized comparison of a durable polymer everolimus-eluting stent with a bare metal coronary stent: the SPIRIT first trial. EuroIntervention. 2005;1:58-65.

18. Tsuchida K, Piek JJ, Neuman F, et al. One-year results of a durable polymer everolimus-eluting stent in de novo coronary narrowings (The SPIRIT FIRST trial). EuroIntervention. 2005;1:266-272.

19. Wiemer M, Serruys PW, Miquel-Hebert K, et al. Five-year long-term clinical follow-up of the XIENCE V everolimus-eluting coronary stent system in the treatment of patients with de novo coronary artery lesions: the SPIRIT FIRST trial. Catheter Cardiovasc Interv. 2010;75: 997-1003.

20. Serruys PW, Ruygrok P, Neuzner J, et al. A randomised comparison of an everolimus-eluting coronary stent with a paclitaxel-eluting coronary stent: the SPIRIT II trial. EuroIntervention. 2006;2: 286-294.

21. Ruygrok PN, Desaga M, Van Den Branden F, et al. One year clinical follow-up of the XIENCE V everolimus-eluting stent system in the treatment of patients with de novo native coronary artery lesions: the SPIRIT II study. EuroIntervention. 2007;3:315-320. 
22. Claessen BE, Beijk MA, Legrand V, et al. Two-year clinical, angiographic, and intravascular ultrasound follow-up of the XIENCE V everolimus-eluting stent in the treatment of patients with de novo native coronary artery lesions: the SPIRIT II trial. Circ Cardiovasc Interv. 2009;2:339-347.

23. Garg S, Serruys P, Onuma Y, et al. 3-year clinical follow-up of the XIENCE V everolimus-eluting coronary stent system in the treatment of patients with de novo coronary artery lesions: the SPIRIT II trial (Clinical Evaluation of the Xience V Everolimus Eluting Coronary Stent System in the Treatment of Patients with de novo Native Coronary Artery Lesions). JACC Cardiovasc Interv. 2009;2:1190-1198.

24. Garg S, Serruys PW, Miqual-Hebert K; on behalf of the SPIRIT II Investigators. Four year clinical follow-up of the XIENCE V everolimuseluting coronary stent system in the treatment of patients with de novo coronary artery lesions: the SPIRIT II trial. Catheter Cardiovasc Interv. 2011;77:1012-1017.

25. Stone GW, Midei M, Newman W, et al. Comparison of an everolimuseluting stent and a paclitaxel-eluting stent in patients with coronary artery disease: a randomized trial. JAMA. 2008;299:1903-1913.

26. Stone GW. Comparison of everolimus-eluting and paclitaxel-eluting stents: first report of the four-year clinical outcomes from the SPIRIT III trial. Abstract presented at the Transcatheter Cardiovascular Therapeutics annual meeting, Washington, DC; September 21-25, 2010.

27. Nikolsky E, Lansky AJ, Sudhir K, et al. SPIRIT IV trial design: a large-scale randomized comparison of everolimus-eluting stents and paclitaxel-eluting stents in patients with coronary artery disease. $\mathrm{Am}$ Heart J. 2009;158:520-526.

28. Stone GW, Rizvi A, Newman W, et al. Everolimus-eluting versus paclitaxel-eluting stents in coronary artery disease. NEngl J Med. 2010; 362:1663-1674.

29. Stone GW. A large-scale randomized comparison of everolimus-eluting and paclitaxel-eluting stents: two-year clinical outcomes from the SPIRIT IV trial. Abstract presented at the Transcatheter Cardiovascular Therapeutics annual meeting, Washington, DC; September 21-25, 2010.

30. Grube E. SPIRIT V Diabetic Trial: 9-month angiographic and 12-month clinical results. Abstract presented at EuroPCR meeting, Paris, France; May 25-28, 2010.

31. Grube E, Chevalier B, Smits P, et al. The SPIRIT V study: a clinical evaluation of the XIENCE V everolimus-eluting coronary stent system in the treatment of patients with de novo coronary artery lesions. JACC Cardiovasc Interv. 2011;4:168-175.

32. Chevalier B. SPIRIT V single-arm study: 2-year follow-up. Abstract presented at EuroPCR meeting, Paris, France; May 25-28, 2010.

33. Hermiller J. Early and late stent thrombosis rates in 5,054 real-world patients from XIENCE V USA with and without dual antiplatelet therapy interruptions. Abstract presented at EuroPCR meeting, Paris, France; May 25-28, 2010.

34. Kedhi E, Joesoef KS, McFadden E, et al. Second-generation everolimuseluting and paclitaxel-eluting stents in real-life practice (COMPARE): a randomised trial. Lancet. 2010;375:201-209.

35. Smits P. COMPARE Trial: 2-year follow-up. Abstract presented at the Transcatheter Cardiovascular Therapeutics annual meeting, Washington, DC; September 21-25, 2010.
36. Ribichini F, Ansalone G, Bartorelli A, et al. A clinical and angiographic study of the XIENCE V everolimus-eluting coronary stent system in the treatment of patients with multivessel coronary artery disease. Study design and rationale of the EXECUTIVE trial. $J$ Cardiovasc Med. 2010;4:299-309.

37. Ribichini F. A clinical and angiographic study of the XIENCE V everolimus-eluting coronary stent system in the treatment of patients with multivessel coronary artery disease. The EXECUTIVE trial. Abstract presented at EuroPCR meeting, Paris, France; May 25-28, 2010.

38. Jensen LO, Thayssen P, Tilsted HH, et al. Rationale and design of a randomized clinical comparison of everolimus-eluting (Xience V/Promus) and sirolimus-eluting (Cypher select+) coronary stents in unselected patients with coronary heart disease. Cardiology. 2010;116:73-78

39. Jensen LO. A prospective, randomized trial of everolimus-eluting and sirolimus-eluting stents in patients with coronary artery disease: the SORT OUT-IV trial. Abstract presented at the Transcatheter Cardiovascular Therapeutics annual meeting, Washington, DC; September 21-25, 2010.

40. Park KW, Yoon JH, Kim JS, et al. Efficacy of Xience/Promus versus Cypher in rEducing Late Loss after stENTing (EXCELLENT) trial: study design and rationale of a Korean multicenter prospective randomized trial. Am Heart J. 2009;157:811-817.

41. Kim HS. Efficacy of Xience/Promus versus Cypher to rEduce Late Loss in stENT. Abstract presented at the Transcatheter Cardiovascular Therapeutics annual meeting, Washington, DC; September 21-25, 2010.

42. Byrne RA. ISAR-TEST 4: two-year clinical and angiographic outcomes from a prospective randomized trial of everolimus-eluting stents and sirolimus-eluting stents in patients with coronary artery disease. Abstract presented at the Transcatheter Cardiovascular Therapeutics annual meeting, Washington, DC; September 21-25, 2010.

43. Onuma Y, Kukreja N, Piazza N, et al. The everolimus-eluting stent in real-world patients: 6-month follow-up of the X-SEARCH (Xience V Stent Evaluated at Rotterdam Cardiac Hospital) registry. J Am Coll Cardiol. 2009;54:269-276.

44. Windecker S. Long-term comparison of everolimus-eluting and sirolimus-eluting stents for coronary revascularization. Abstract presented at the European Society of Cardiology Congress, Stockholm, Sweden; August 28-September 1, 2010.

45. Serruys PW, Silber S, Garg S, et al. Comparison of zotarolimus-eluting and everolimus-eluting coronary stents. $N$ Engl J Med. 2010;363: 136-146.

46. Silber S, Windecker S, Vranck P, Serruys PW. Unrestricted randomised use of two new generation drug-eluting coronary stents: 2-year patient related versus stent-related outcomes from the RESOLUTE All Comers trial. Lancet. 2011;377:1241-1247.

47. Meredith IT, Whitbourn R, Scott D, et al. PLATINUM QCA: a prospective, multi-centre study assessing clinical, angiographic, and intravascular ultrasound outcomes with the novel platinum chromium thin strut PROMUS Element everolimus-eluting stent in de novo coronary stenoses. EuroIntervention. 2011;7:84-90.

48. Stone GW, Teirstein PS, Meredith IT, et al. A prospective, randomized evaluation of a novel everolimus-eluting stent: the PLATINUM trial. J Am Coll Cardiol. 2011;57:1700-1708.
Medical Devices: Evidence and Research

\section{Publish your work in this journal}

Medical Devices: Evidence and Research is an international, peerreviewed, open access journal that focuses on the evidence, technology, research, and expert opinion supporting the use and application of medical devices in the diagnosis, treatment and management of clinical conditions and physiological processes. The identification of novel
Dovepress

devices and optimal use of existing devices which will lead to improved clinical outcomes and more effective patient management and safety is a key feature. The manuscript management system is completely online and includes a quick and fair peer-review system. Visit http://www. dovepress.com/testimonials.php to read real quotes from authors. 